Ojca oraz uświęcony mocą Ducha Świętego. „Kościół jest na tyle sobą, na ile relacje jego członków są odwzorowaniem idealnych relacji interpersonalnych Osób Trójcy Świętej” (s. 257). Najgłębsza istota Kościoła, a także jego zbawcza działalność tylko wtedy jest w pełni zachowywana oraz realizowana, gdy pozostaje on wierny swej trynitarnej genezie oraz trynitarnej naturze.

Warto zaznaczyć, że wszystkie, omawiane w powyższej monografii treści oraz prezentowane tezy i postulaty, nie wypływają z apriorycznych założeń, lecz oparte są na rzetelnej analizie przebogatego materiału źródłowego, jakim są dzieła Ojców Kościoła. Autor przywołując szereg określeń Kościoła mało znanych w teologii, w szczególności z pism św. Paulina z Noli, ubogaca tym samym bazę źródłową eklezjologii nie tylko patrystycznej, ale i ogólnej, co stanowi dodatkową zaletę omawianej monografii.

Omawiana praca, będąca swego rodzaju „ukoronowaniem” dotychczasowej twórczości naukowej ks. J. Pałuckiego, która dotyczy patrystyki, patrologii oraz historii teologii, w szczególności zaś eklezjologii i aretologii patrystycznej, odznacza się dużymi walorami naukowymi. Przedstawiony w niej materiał jest głęboko źródłowy, poprawny metodologicznie, krytyczny, wyważony i precyzyjny.

Autor słusznie konstatuje, że dotychczasowe opracowania oparte na źródłach patrystycznych, ograniczające się często do tekstów pojedynczych Ojców Kościoła, eksponują priorytetowo ujęcia chrystocentryczno-soteriologiczne, bądź instytucjonalne lub mariologiczne w eklezjologii pierwszych wieków. Te studia, o charakterze przyczynkowym, skądinąd wartościowe i pożyteczne, nie ukazują jednak w pełni całej natury Kościoła, który w swej genezie i najgłębszej istocie, jest ikoną Trójcy Świętej w ujęciu zarówno globalnym jak i sumarycznym, co z powodzeniem wykazał ks. Pałucki.

Ks. Franciszek Drączkowski - Lublin, KUL

\title{
Ks. Jerzy PAŁUCKI, Trynitarny wymiar Kościoła. Studium patrystyczne, Lublin 2007, Wydawnictwo KUL, ss. 320.
}

Swą książkę Ksiądz Profesor Jerzy Pałucki sytuuje w kontekście wspólnotowej refleksji nad rzeczywistością Kościoła, która od czasu Nadzwyczajnego Synodu Biskupów z 1985 r. - stała się na nowo punktem zainteresowaniaํ․ Szczególne

${ }^{1}$ Efektem powrotu do źródeł - dokonanym przed Soborem Watykańskim II i potwierdzonym przez to zgromadzenie - było ujęcie rzeczywistości Kościoła jako misterium, którego centrum, źródło i szczyt stanowi historiozbawcza obecność i zaangażowanie się Boga w Trójcy Osób: „Cały Kościół ukazuje się jako »jako lud zjednoczony jednością Ojca i Syna, i Ducha Świętego«” (KK 4). Na kilkanaście lat przed wspomnianym Synodem podstawy eklezjologii wspólnoty na gruncie polskiej teologii pastoralnej wypracował Sługa Boży, ks. Franciszek Blachnicki (1921-1987) (Teologia pastoralna ogólna, cz. 2: Eklezjologiczna dedukcja teologii pastoralnej, Lublin 1971, 159-341; dalej używam skrótu: Blachnicki, TPO II). Eklezjologia Konstytucji dogmatycznej o Kościele jest jak to ujął Ksiądz Blachnicki - eklezjologia Bożej obecności, a jej rezultatem i konsekwencją jest 
zainteresowanie Autora dotyczy podmiotowego rozumienia Kościoła: „Punktem wyjścia, niejako inspiracją do podjęcia niniejszego tematu, była lektura korespondencji św. Ambrożego, św. Augustyna i św. Paulina z Noli z Sulpicjuszem Sewerem, św. Hieronimem i wielu innymi [...]. To prowokowało do zapytania, jak oni Kościół rozumieli, czym, a raczej Kim, jest on dla nich" (s. 26)².

eklezjologia wspólnoty. Jak pisał Ksiądz Blachnicki „soborowa wizja Kościoła nie pojawiła się jak deus ex machina. Jest ona wynikiem i ukoronowaniem ewolucji z górą stuletniej, której sens można streścić jako przejście od wizji Kościoła ujętego w kategoriach socjologiczno-prawnych, jako «societas perfecta», do wizji Kościoła jako «communio sanctorum», albo jako przejście od eklezjologii władzy (hierarchologii) do eklezjologii wspólnoty-komunii” (Blachnicki. TPO II s. 169). Tuż przed Soborem ukazało się studium Jérôme Hamera (1916-1996) - L'Église est une communion (Paris 1962), „książka, która stanowi syntezę badań prowadzących do biblijnej i patrystycznej rzeczywistości Kościoła jako wspólnoty” oraz Ferdinanda Holböcka (1913-2002) - Das Mysterium der Kirche in dogmatischer Sicht (w: Misterium Kirche in der Sicht der theologischen Disziplinen, Bd. 1-2, hrsg. F. Holböck - Th. Satory, Salzburg 1962 - Bd. 1, s. 201-346), który ujmuje Kościół jako wspólnotę. „Nie wyprowadza on pojęcia wspólnoty z Pisma św. i z objawienia, z biblijno-greckiego pojęcia koinōnia, ale z naturalnych kategorii socjologicznych. Dlatego pozostaje w gruncie rzeczy na linii tradycyjnej eklezjologii z jej socjologicznym i prawno-organizacyjnym punktem wyjścia" (Blachnicki, TPO II 175-178. Jeszcze przed zakończeniem Soboru ukazało się opracowanie ks. Ferdinanda Klostermanna (1907-1982) - Prinzip Gemeinde. Gemeinde als Prinzip des kirchlichen Lebens und der Pastoraltheologie als Theologie dieses Lebens (Wien 1965), w którym ,podjął próbę opracowania szczegółowej struktury przedmiotu materialnego” teologii pastoralnej. W tej pracy wiedeński pastoralista doszedł do następującego wniosku: „Jeśli teologia pastoralna ma być teologią życia Kościoła (Theologie des kirchlichen Lebensvollzuges), a Kościół istnieje zasadniczo nie jako suma jednostek, ale jako wspólnota, nauka o wspólnocie, o jej istocie, strukturze, prawach życia i rozwoju musi zająć w niej pozycję centralną i kluczową. Cała teologia pastoralna we wszystkich swoich częściach i dyscyplinach szczegółowych musi być w jakiś sposób odniesiona i skierowana do tej nauki o wspólnocie” (Blachnicki, TPO II 135-136). Po Soborze Watykańskim II „najwcześniej kategorię communio odkrywał w tekstach Soboru G. Philips" (L'Église et son mysterè au II ${ }^{e}$ Concile du Vatican, t. 1-2, Paris 1966). W latach siedemdziesiątych powstały „dwie prace wnikliwie analizujące pojęcie communio w dokumentach soborowych. Chodzi o dzieło Oskara Saiera «Communio» in der Lehre des Zweiten Vatikanischen Konzils. Eine rechtsbegriffliche Untersuchung (München 1973) i rozprawę Hansa Rossiego - Die Kirche als personale Gemeinschaft. Der kommunitäre Charakter der Kirche nach den Dokumenten und Akten des Zweiten Vatikanischen Konzils (Köln 1976). Opracowania po 1985 r. odnoszą się najczęściej do tych dwóch publikacji. Są jednak i inne, np. H. Wieh, Konzil und Gemeinde. Eine systematisch-theologische Untersuchung zum Gemeindeverständnis des Dokumenten und Akten des Zweiten Vatikanischen Konzils in pastoraler Absicht (Köln 1976). U nas R. Sobański wskazywał na doniosłość soborowej kategorii communio dla eklezjologii prawnej: Kościót jako podmiot prawa. Elementy eklezjologii prawnej (Warszawa 1982); «Communio» als Formalprinzip des kirchlichen Rechts, ThG 72 (1982) 175-188. Na naszej scenie teologicznej pojawiły się przede wszystkim znaczące dla eklezjologii communio przekłady, m.in. dwie książki: J. Ratzingera - Kościót wspólnota, tłum. W. Życiński (Lublin 1993) i P.J. Cordesa - Communio. Utopia czy program?, tłum. B. Widła (Warszawa 1996) oraz artykuły zamieszczone zwłaszcza w dwóch numerach „Communio” (6:1986, nr 4 oraz 9:1989, nr 3); por. też A. Czaja, Credo in Spiritum Vivificantem. Pneumatologiczna interpretacja Kościoła jako komunii w posoborowej teologii niemieckiej, Lublin 2003, s. 15, przyp. 5-6.

${ }^{2}$ Podkreślenie moje: M.M. 
Podmiotowe ujęcie bytu Kościoła stanowi jedno ze szczegółowych ujęć potwierdzających zasadność rozumienia Kościoła jako wspólnoty ${ }^{3}$ To, co dotychczas napisaliśmy, tłumaczy zainteresowanie teologa pastoralisty pracą teologa patrysty. Na gruncie teologii pastoralnej nie jest to wcale takie rzadkie, by wspomnieć tylko - tytułem przykładu - wybitną pracę Karola Delahaye - Erneuerung der Seelsorgsformen aus der Sicht der frühen Patristik. Ein Beitrag zur theologischen grundlegung kirchlicher Seelsorge, Freiburg i. Br. $1958^{4}$.

Materiał badawczy recenzowanej książki stanowi ,epistolografia patrystyczna czterech pierwszych wieków po narodzeniu Chrystusa” (s. 29), ograniczona wprawdzie do czterech autorów, ale - w przekonaniu Autora znamienita, bo „mieli oni już do dyspozycji nauczanie teologów minionych czterech wieków, całe bogactwo doświadczenia Kościoła" (s. 27). Oznacza to, że znajdziemy tu odniesienia do tych starożytnych pisarzy Kościoła, których „działalność literacka wywarła najważniejszy wpływ, na naszych trzech głównych Autorów oraz innych teologów przełomu czwartego i piątego wieku, a więc szczególnie: Orygenesa, Klemensa Rzymskiego i Klemensa Aleksandryjskiego, Cypriana oraz Ireneusza" (s. 29).

Jeśli chodzi o zwrócenie uwagi na literaturę, a szczególnie tę, która dotyczy zagadnienia pracy Księdza Pałuckiego, to należy uznać za mocno przesadzone stwierdzenie, że ,nie podjęto całościowego opracowania głównych nurtów eklezjologii patrystycznej ze szczególnym uwzględnieniem wymiaru trynitarnego, rozpatrywanego w aspekcie relacji interpersonalnych" (s. 29). Wystarczy bowiem

${ }^{3}$ Tak to rozumiał Karol Wojtyła jako arcybiskup Krakowa i autor pierwszej syntezy nauki Soboru Watykańskiego II, por. M. Marczewski, Posługa zbawcza Kościoła w ujęciu ks. Franciszka Blachnickiego, Lublin 2000, 197: „Arcybiskup krakowski uważa, że nie należy i nie można ujmować rzeczywistości Kościoła w kategoriach tylko «przedmiotu», bo - jak to wykazał papież Paweł VI pytanie, jak Kościół doby Soboru Watykańskiego II pojmuje sam siebie, było skierowane do Kościoła jako «podmiotu», a więc do wszystkich, którzy ten podmiot tworzą: «'Podmiot Kościół’ jest bowiem jedyną w swoim rodzaju wspólnotą«. Co więcej - ujęcie Kościoła jako «podmiotu» wyrasta z traktowania go w kategoriach wspólnoty (communio)". Na temat Kościoła ujmowanego w kategoriach podmiotu zob. też obszerne studium Hervé M. Legranda - Die Entwicklung der Kirchen als verantwortliche Subjekte: eine Anfrage an das II. Vatikanum, w: Kirche im Wandel. Eine kritische Zwischenbilanz nach dem Zweiten Vatikanum, hrsg. G. Alberigo - Y. Congar - H.J. Pottmeyer, Düsseldorf 1982, 141 174, spec. s. 142: „Zunächst will ich erklären, warum ich diesen Terminus gewählt habe, der ja in den Texten des II. Vatikanums nicht vorkommt. Der konziliare und traditionelle Begriff, der am ehesten die oben beschreibene Wirklichkeit träfe wäre wohl der der communio. Aber er erscheint mir zu weit und nicht genau genug, um mit der gleichen Präzision wie die Begriffe «Kirche von Subjekten» und «Kirche als Subjekt» diese beiden spezifischen Sichtweisen einzukreisen, die der communio-Ekklesiologie entspringen; es kommt hinzu, daß mit dem Begriff communio auch noch andere bereiche abgedeckt werden, deren angemessene Erklärung den Rahmen der vorliegenden Studie sprengen würde".

${ }^{4}$ Autor ukazał w niej znaczenie, jakie odgrywa w literaturze patrystycznej pierwszych stuleci Kościoła obraz niewiasty, będącej jednocześnie dziewicą i matką, dla wyrażenia istoty Kościoła, jego pośrednictwa, roli, granic i możliwości „w odniesieniu do procesu zbawczego, por. Blachnicki, TPO II 66-88. 
odnieść się do cyklu opracowań o Kościele, które ukazały się w serii wydawniczej Handbuch der Dogmengeschichte ${ }^{5}$. Szkoda, że Autor nie sięgnął także do cytowanego wyżej tekstu ks. Delahaye.

Książka składa się z wstępu, trzech rozdziałów, zakończenia, bibliografii, streszczeń i indeksu autorów ${ }^{6}$. Całość dopełnia wykaz skrótów oraz spis treści w języku polskim, włoskim i angielskim. W rozdziale pierwszym (s. 41-105) zainteresowanie Księdza Pałuckiego koncentruje się wokół (1) ukazania Kościoła wspólnoty w kontekście wspólnoty Osób Bożych i roli każdej z nich w bycie Kościoła. U podstaw podmiotowego rozumienia Kościoła leży jego rozumienie jako rzeczywistości osobowej, by użyć wyrażenia Księdza Profesora Czesława Bartnika, ,zapodmiotowanej w osobie indywidualnej i zarazem w «osobie» społecznej” 7 . Dlatego treści rozdziału drugiego (s. 107-169) dotyczą refleksji nad (2) rzeczywistością osoby i roli osób, które odegrały i odgrywają znaczącą rolę w Kościele: Niepokalana Matka Kościoła i wspólnota świętych. W rozdziale ostatnim (s. 171247) Ksiądz Profesor (3) wskazał na konstytutywne elementy Kościoła, które potwierdzają prawdę, że „cały Kościół ukazuje się »jako lud zjednoczony jednością Ojca i Syna, i Ducha Świętego«,,(KK 4). Są nimi: communio, institutio i missio.

1. Wprawdzie refleksja nad fenomenem osoby ludzkiej stanowi przedmiot refleksji Autora przedstawionych w drugiej części pracy, to jednak u postaw zaistnienia rzeczywistości Kościoła jako dzieła Osób Trójcy Świętej, sytuuje fakt stworzenia człowieka „na obraz Trójcy Świętej” , i to „nie tylko w wymiarze personalnym, ale także interpersonalnym - społecznym oraz uniwersalnym (św. Augustyn), co sprawia, że zasiane w osobie ludzkiej „ziarno dążenia do dosko-

${ }^{5}$ Por. m.in. P.V. Dias, Kirche in der Schrift und im 2. Jahrhundert, Freiburg - Basel - Wien 1974; P.T. Camelot, Die Lehre von der Kirche. Väterzeit bis ausschließlich Augustinus, Freiburg - Basel - Wien 1970; Y.M.J. Congar, Die Lehre von der Kirche. Vom Augustinus bis zum Abendländischen Schisma, Freiburg - Basel - Wien 1971; tenże, Die Lehre von der Kirche. Vom Abendländischen Schisma bis zur Gegenwart, Freiburg - Basel - Wien 1971. Wprawdzie Autor cytuje tekst Camelota, ale zamieszcza złe strony, więc można przypuszczać, że nie czytał.

${ }^{6}$ Wykaz skrótów (s. 19-22); Wstęp (s. 23-39); Rozdz. I: „Bóg jeden w Trójcy Osób genezą i wzorem Kościoła" (s. 41-105: 1. Trójca Święta a Kościół, 2. Bóg Ojciec a Kościół, 3. Syn Boży a Kościół, 4. Duch Święty a Kościół); Rozdz. II: „Odzwierciedlenie osobowych relacji trynitarnych w Kościele apostolskim” (s. 107-169: 1. Pojęcie «osoby» i jego akomodacja eklezjologiczna, 2. Działanie Osób Trójcy Świętej w Kościele przez Maryję, 3. Osobowe wzorce Kościoła - Apostołowie: Piotr, Jan i Paweł); Rozdz. III: „Konstytutywne elementy Kościoła odzwierciedleniem jego trynitarnej natury" (s. 171-247: 1. Kościół - Communio, 2. Kościół - Institutio (societas), 3. Kościół - Misterium, 4. Kościół - Missio); Zakończenie (s. 249-257); Bibliografia (s. 259-288); [Streszczenia] (s. 288-311); Indeks autorów (s. 313-320).

${ }^{7}$ Cz.S. Bartnik, Osobowy byt Kościoła, w: tenże, Teologia społeczno-polityczna, Lublin 1998, 189; podkreślenie moje: M.M; por. także: Cz.S. Bartnik, Personalizm, Lublin 1995. Warto również zwrócić uwagę na rozdział II: „W kręgu podmiotów społeczno-politycznych” jego Teologii spoteczno-politycznej, s. 113-215, oraz teksty krótkie, ale bardzo treściwe: Prozopoiczna struktura Kościoła, w: Personalizm, s. 219-221; Społeczność eklezjalna, w: Teologia społeczno-polityczna, s. 170-174; Chrystus ,,spoleczny”, w: Teologia spoleczno-polityczna, s. 175-176. 
nałej jedności na wzór jedności trynitarnej” sprawia, że „możemy podejmować starania, by nie tylko się do niej przybliżyć, ale także na jej wzór kształtować nasze formy współżycia w tym świecie" (s. 53). Tak więc można mówić o pewnej formie stygmatyzacji osoby ludzkiej, co w kilkanaście stuleci później, w nauce Soboru Watykańskiego II, przybrało formę konstatacji, że „[...] człowiek, będąc jedynym na ziemi stworzeniem, którego Bóg chciał dla niego samego, nie może odnaleźć się w pełni inaczej jak tylko poprzez bezinteresowny dar z siebie samego" (KDK 24). Wskazanie na Trójcę Świętą jako wzoru i źródła dla wszystkich innych wspólnot, w tym szczególnie dla Kościoła, pozwala jednocześnie na podkreślenie podmiotowości każdej z osób tworzących communio: „To dzięki właśnie nadzwyczajnej relacji Osób Trójcy Świętej Kościół z jednej strony jest doskonałą communio, z drugiej zachowuje równocześnie wielość i podmiotowość poszczególnych jego członków" (s. 54).

Interesujące jest prześledzenie roli każdej z Osób Trójcy w powołaniu do życia Kościoła. W teologii zwykło się od czasu o. Karla Rahnera TJ (1904-1984) podkreślać znaczenie jego najbardziej oryginalnego wkładu do współczesnej teologii trynitarnej, że „Trójca «ekonomii» jest Trójcą immanentną, i odwrotnie". Pozwala ona na wypracowanie obrazu Kościoła jako wspólnoty życia z Ojcem przez Chrystusa w Duchu Świętym, która staje się równocześnie podstawą zaistnienia realnej wspólnoty międzyludzkiej.

Odwołanie się do roli poszczególnych Osób w dziele powołania Kościoła jest niezwykle ujmujące: „Orygenes, a za nim wielu Ojców Kościoła, wyraźnie poucza, że Kościół istnieje w «sercu» Boga Ojca od samego początku jako Oblubienica przygotowana dla Oblubieńca" (s. 63, 73) ${ }^{9}$. Podobnie nauczał św. Ambroży, który rozwinął obraz winnicy: „Winnicą jest Kościół, Ogrodnikiem

${ }^{8}$ Por. Y.M.J. Congar, Wierze w Ducha Świętego, t. 3. tłum. L. Rutowska, Warszawa 1996, 27-36; zob. także Blachnicki, TPO II 372-374. Autorowi prezentowanej publikacji trudno jednak wydobyć się z oków myślenia apriopracyjnego w trakcie prezentowania roli każdej z Osób Bożych w ekonomii zbawienia.

${ }^{9}$ Zanim podejmiemy ten wątek myślę, że warto zwrócić uwagę, że myśl o powołaniu Kościoła uprzedził fakt ustanowienia wspólnoty małżeńskiej na odniesienie do początku stworzenia, do rzeczywistości sakramentu najpierwotniejszego (Jan Paweł II, Mężczyzna i niewiasta stworzyt ich. Odkupienie ciała a sakramentalność małżeństwa, Città del Vaticano 1986, 77 i 375), który wyłonił się z «sakramentu stworzenia» (M. Marczewski, «Sakrament najpierwotniejszy». Sakramentalność matżeństwa w ujęciu Jana Pawła II, „Ethos” 11:1998, nr 3, 93-104): „Ustanowienie małżeństwa wedle słów Rdz 2, 24 wyraża nie tylko zapoczątkowanie podstawowej ludzkiej wspólnoty, która poprzez właściwą sobie moc «prokreacji» («Bądźcie płodni rozmnażajcie się»-Rdz 1, 28) służy kontynuowaniu kreacji przedłużaniu dzieła stworzenia - wyraża ono równocześnie zbawczą inicjatywę Stwórcy, odpowiadającą odwiecznemu wybraniu człowieka, o jakim mówi List do Efezjan [1,3-14]. Owa zbawcza inicjatywa pochodzi od Boga - Stworzyciela, a jej nadprzyrodzona skuteczność utożsamia się z samym aktem stworzenia człowieka w stanie pierwotnej niewinności. W stanie tym od razu w akcie stworzenia człowieka zaowocowało odwieczne jego wybranie w Chrystusie; w ten sposób należy przyjąć, że cały ów pierwotny »sakrament stworzenia« ma swoją skuteczność od «Umiłowanego» (por. Ef 1, 6, gdzie mowa o «łasce, którą obdarzył nas w Umiłowanym»)" (Jan 
Bóg Ojciec, który od zawsze i na zawsze »uprawia« winnicę - Kościół” (s. 64). Ojciec też jest „przyczyną każdej rzeczywistości i każdego działania” (s. 66), do Niego „należy przywilej powołania oraz posłania i to zarówno w relacjach wewnątrz trynitarnych, jak i w stosunku do człowieka i Kościoła" (s. 69). Syn i Duch Święty to dwie ręce Ojca (św. Ireneusz - s. 73).

Syn Boży działa z woli Ojca i pozostaje w bezustannej jedności z Duchem Świętym. Z tej też racji w tekstach Ojców „Syn nazywany bywa »Ikoną Piękna« Ojca, a Duch Święty wiecznym »Objęciem Obu«, a także węzłem łączącym Odwiecznego i historię" (s. 74). Z racji związku Syna z Ojcem Jezus nazwany jest jego myślą (św. Ignacy Antiocheński), prawdziwym światłem (Paulin z Noli), i że działa od początku (św. Ireneusz), co św. Augustyn spuentował nauką o Ecclesia ab Abel, że ,sprawiedliwi, którzy żyli przed Wcieleniem Chrystusa, należą do Jego Ciała - Kościoła, a jeśli coś się zmienia, to czasy, a nie wiara" (s. 77).

Jest on Mądrością Ojca i "naucza w obu Testamentach” (Klemens Aleksandryjski, Orygenes - s. 78), a także Oblubieńcem Kościoła. To On, by wybiec w przyszłość, a przecież pozostając w tym strumieniu łaski, „Chrystus zawsze przyłącza do siebie Kościół, swoją Oblubienicę, która wzywa swego Pana i przez Niego oddaje cześć Ojcu wiecznemu" (KL 7; por. KK 4).

Uczniowie po śmierci i chwalebnym zmartwychwstaniu Pana spotykali się z Nim i widzieli „w przemienionej przez Ducha cielesności” (s. 91); był to więc nie pierwszy dar Ducha Świętego - soma pneumatikon oddany Synowi przez Ojca na nowo, gdy ten na krzyżu oddał Ojcu Ducha Świętego. Dzięki Niemu w Kościele jest stale obecna Prawda Boża, „gdyż Duch jest Prawdą” (s. 97). Z kolei Tertulian poucza, że ,przekaz wiary oraz rozwój teologii może mieć miejsce tylko w Kościele" (s. 98). On też jest sprawcą jedności (s. 97-98). Jak jednak zachować się wobec zdecydowanego przekonania św. Augustyna, że „kto nie jest w tym Kościele [...] nie otrzymuje Ducha Świętego"? (s. 98). Tym bardziej, że przekonanie Kościoła w tej sprawie jest inne ${ }^{10}$. Duch Święty jest przede wszystkim uznawany i ukazywany jako twórca modelu Kościoła ,jedności w wielości”, a także gwarant jednomyślności „co do wiary i obyczajów” (s. 99-100).

Trzeba powiedzieć, że rola Ducha Świętego została w tej części potraktowana niezwykle skromnie, by nie powiedzieć po macoszemu. Wystarczyło by bowiem sięgnąć do opracowania Księdza Profesora Bogdana Częsza Pneumatologia Ojców Kościoła ${ }^{11}$, zamiast zajmować się mętnymi dywagacjami Księdza Częsza na temat Mühlenowskiej pneumatologii (s. 101-102). Mętnymi, bo - albo źle przedstawionymi przez Księdza Pałuckiego, albo źle zrozumianą przez Księdza Częsza pneumatologią Dogmatyka z Paderborn.

\footnotetext{
Paweł II, jw. s. 378). To wszystko uzasadnia ustawiczne odwołanie się Kościoła do obrazu małżeństwa jako swego poniekąd pierwowzoru.

${ }^{10}$ Por. DM 4; E. Sakowicz, Duch Święty tajemniczo obecny w religiach i kulturach niechrześcijańskich, w: Duch, który jednoczy. Zarys pneumatologii, red. M. Marczewski, Lublin 1998, 253-258.

${ }^{11}$ Por. B. Częsz, Pneumatologia Ojców Kościoła, w: Duch, który jednoczy. Zarys pneumatologii, s. 73-117.
} 
2. Rozdział drugi (s. 107-169) jest poświęcony ukazaniu szczególnej roli osób, które tworzą wspólnotę osób, bo poddały się wpływowi Osób Trójcy i stają się ich stugami w Kościele ${ }^{12}$; jak Syn Boży stał się stuga, by plan Ojca mógł zostać zrealizowany (zob. Rz 15, 8), tak ci, którzy włączają się posłanie Ojca, stają się stugami i stużebnicami w Bożym planie zbawienia.

Tym, który pociaga/powołuje, jest Ojciec (J 6, 44). Pierwszym pociagniętym przez Ojca jest Syn Boży. Drugim w porządku Wcielenia - jest jego Matka. Kościół widzi w niej wzór dla siebie. Dlatego od początku ujmuje siebie w obrazie matki: Ecclesia mater - mater Ecclesiae (s. 117), jest jego pierwowzorem/ typus (św. Ambroży, s. 118). Paulin z Noli „określa Kościół jako łono Matki”, w którym „możemy sie rozwijać bez lęku, że zostaniemy wyrzuceni (abortiti)" (s. 122-123).

Znaczenie Maryi w dziele zbawienia wyjaśnia św. Ireneusz w paraleli o pierwszym i drugim Adamie oraz o pierwszej i drugiej Ewie. Jak Chrystus przywrócił człowieczeństwo pierwszego Adama do pierwotnego stanu, tak Maryja - swym posłuszeństwem - doprowadza do pierwotnego stanu zniszczoną harmonię (por. s. 138), a skażony przez Ewę śmiercią rodzaj ludzki został przez Maryję obdarowany życiem: „[...] śmierć przez Ewę, życie przez Maryję” (św. Augustyn, s. 139). Zresztą ten obraz Maryi w historii zbawienia jest o wiele bogatszy (zob. s. 139-142), choć samemu planowi relacji, jakie znamionują odniesienia Maryi i Kościoła w myśli Ojców, brak w książce teologicznej przejrzystości i głębi. Myślę, że wiele by tu pomogła lektura o. Yves Congara ${ }^{13}$.

Kolejne osoby powołane, będące wzorcami dla Kościoła, to apostołowie: św. Piotr, św. Jan i św. Pawe ${ }^{14}$. Święty Piotr określony został mianem „,figury Kościoła zawierzenia" (s. 145). Jednak temat ten nie został rozwinięty przez Autora. Święty Jan został nazwany „figurą Kościoła kontemplującego” zmartwychwstanie (s. 155), radującego się „widokiem pustego grobu” (s. 157). Święty Pawel stanowi „figurę Kościoła nawracającego się” (s. 159). Za św. Augustynem Ksiądz Profesor Pałucki przypomina, że droga ewangelizacji pozostaje wciąż otwarta dla wszystkich, a sam Pan, „także po Wniebowstąpieniu, osobiście ingeruje w sprawy Kościoła i wciąż ukazuje kierunki jego działania” (s. 159).

${ }^{12}$ Zagadnieniem nie rozwiązanym przez Autora, a tu jedynie zaznaczonym jest pytanie o to, co znaczy, że Kościół jest osobą? Trudno się zgodzić z tym, by Kościół stawał się osobą poprzez numeryczne dodawanie osób/dusz (s. 112-113). Z pewnością przedstawienie ujęcia kard. Urs von Balthasara za S. Ackermannem, że „osobowe pojmowanie Kościoła jest jedynie eklezjologicznym zagęszczeniem słów samego Chrystusa: «aby wszyscy stanowili jedno, jak Ty, Ojcze we Mnie, a Ja w Tobie, aby i oni stanowili w Nas jedno, by świat uwierzył, że Ty mnie posłałeś» (J 17, 21)" (s. 114) jest jakimś rozwiązaniem. Należałoby jednak wyjaśnić naturę owego „zagęszczenia”. Wyjaśnienia osobowej natury Kościoła należy szukać w Mühlenowskiej pneumatologicznej eklezjologii.

${ }^{13}$ Por. Y. Congar, Marie et l'Église dans le pensée patristique, RSPT 38 (1954) 3-38.

${ }^{14} \mathrm{Na}$ marginesie dodajmy, że cytowane w przyp. 100, 102, 105 teksty pochodzą z KK, a nie z KDK i nie są one tu potrzebne. Zresztą Autor wielokrotnie odbiega od zasadniczego tematu pracy, co czyni ją nieczytelną, by nie powiedzieć nie do końca przemyślaną. 
3. W rozdziale trzecim (s. 171-247) Autor wskazuje na cztery wymiary Kościoła, które potwierdzają, że wywodzi się z trynitarnego źródła. Tak bowiem rozumiemy tytuł rozdziału (Konstytutywne elementy Kościoła odzwierciedleniem jego trynitarnej natury). Inne rozumienie byłoby dogmatycznie podejrzane. Istotną okazuje się tu uwaga Księdza Pałuckiego: „,...] jeśli chcemy należycie rozpoznać czym, lub kim jest Kościół jako communio i societas - to musimy uznać jego misteryjność" (s. 171, 200). Tak więc, choć porządek refleksji zagadnienie misterium uwzględnia jako punkt trzeci, my już na początku musimy pytać, w jakim związku pozostają do siebie communio i mysterium, co Autor rozumie pod pojęciem misteryjności? ${ }^{15}$ „Kościół jako Misterium - pisze on - działa misteryjnie, a więc przez misteria: sakramenty, słowo Boże oraz figury, zapowiadające dzieła Boga i przybliżające Jego w nas działanie" (s. 199). Myśl tę rozwija odnosząc się w tym miejscu do wymiaru Kościoła jako societas: „Można powiedzieć, że już w wymiarze społecznym Kościoła zakodowany jest jego wymiar sakramentalny [...]. Żyje on na podobieństwo Osób Boskich i spełnia w świecie funkcję «sakramentu zbawienia». Jest nie tylko znakiem obecności Boga, ale też skutecznym Jego narzędziem zbawczym" (tamże). Nie znajdziemy jednak potwierdzenia tych konstantacji w nauce Ojców. Szkoda - choć nie wiem, czy to nie za wcześnie, by oczekiwać już takiego rozwoju doktryny.

Wymiar communio Kościoła został przybliżony przez pouczenie św. Ambrożego ecclesia mari comparatur: jak morze przyjmuje wszelkie wpływające doń rzeki, tak od chwili włączenia się osób w communio ecclesiae, stają się one „uczniami Chrystusa, przyjmując smak soli Ewangelii i podejmując trud stawania się «jednią»,,(s. 172-173).

Kościół jako institutio (societas) z samego faktu, że jest w świecie, wymaga tworzenia instytucji i trwałych struktur wewnętrznych, nie tylko, by dokonać dogłębnej, wewnętrznej chrystianizacji, ale - jak za czasów św. Leona Wielkiego

${ }^{15} \mathrm{~W}$ refleksji teologiczno pastoralnej Księdza Blachnickiego nad rzeczywistością Kościoła jako wspólnoty (communio) ów związek posiada znaczenie zasadnicze. Nadaje szczególne znaczenie nauczaniu o Kościele jako wspólnocie. Wnikliwa refleksja nad treścią soborowego nauczania doprowadziła go do stwierdzenia, że wszelkie obrazy, stosowane na wyrażenie tajemnicy Kościoła, wskazują w istocie rzeczy na wspólnotę ,jako na oznaczaną rzeczywistość i najgłębszą treść” (Blachnicki, TPO II, s. 294); określił je mianem cząstkowych, etapów na drodze w dążeniu do wspólnotowego ujęcia istoty Kościoła. Tak jest w przypadku określenia Kościoła jako Ciała Mistycznego naszego Pana (tamże, s. 172-173) czy ludu Bożego (tamże s. 178-193), jako najbardziej reprezentatywnych ujęć. One jednak, by zostały dobrze zrozumiane, domagają się „wyjaśnienia przez ideę wspólnoty” (tamże, s. 204), co zostało kapitalnie spuentowane przez Księdza Blachnickiego na przykładzie określenia lud Boży (tamże, s. 193). Jest natomiast jedno określenie, wprowadzone przez Ojców Soboru Watykańskiego II na opisanie rzeczywistości Kościoła, które „dodaje do pojęcia wspólnoty, jaką jest Kościół, coś istotnego, czego nie można z niego wyprowadzić. Jest to określenie Kościoła jako sakramentu" (tamże, s. 204-205). To sprawia, że określenie Kościoła jako wspólnoty nie wyczerpuje ani nie wyjaśnia dokładnie rzeczywistości, jaką jest Kościół i do zrealizowania której winien dążyć: „Nie wystarczy mówić: Kościół jest wspólnotą, lecz trzeba określić dokładniej: Kościót jest wspólnota sakramentem albo sakramentem wspólnoty" (tamże, s. 205). 
- doprowadzić do pokojowego spotkania dwóch światów: upadającego świata naznaczonego kulturą grecko-rzymską i żywiołu ludów barbarzyńskich (s. 196197). W istocie chodzi o ciągłe podejmowanie prób doskonalenia doczesności (s. 198).

Kościół jest posłany, a jego missio posiada swe najgłębsze źródło w posłaniu Syna i Ducha Świętego. Sam Kościół wreszcie uczestniczy w paschalnym posłaniu, skierowanym do uczniów: „Idźcie na cały świat i nauczajcie wszystkie narody” (Mt 28, 19). Ksiądz Pałucki zaznacza, że „missio Kościoła jest naturalną konsekwencją communio Kościoła" (s. 231), ale nie wyjaśnia dlaczego. Nie wydaje się to tak oczywiste; przynajmniej dla mnie. W jego przekonaniu „literackim pierwowzorem misyjnej aktywności Kościoła może być Justynowy Dialog z Żydem Tryfonem" (s. 239). Głoszenie Ewangelii całemu światu przez apostołów, w przekonaniu św. Paulina z Noli, swe umocnienie zyskało nie tylko przez otrzymane nauczanie, ale także nadzwyczajną łaskę wiary (tamże), a łączyło się ono z misją miłosierdzia, przebaczenia i wezwania do pokuty (s. 243).

Prezentowana książka wiele utraciła poprzez współczesne odwołania. Dyskurs bowiem powinien pozostać na płaszczyźnie refleksji patrystycznej. Wprowadzenie tych odniesień sprawiło, że Autor miejscami wprowadza język mówiony, co w konsekwencji sprawia wrażenie, że mamy do czynienia z jakąś formą kazania. Zbyt wiele jest $w$ niej odniesień do formowania się dogmatów W starciu z herezjami, które nie są tu potrzebne, bo nie wnoszą istotnych treści w zasadniczy problem. Podstawowe bowiem zagadnienia, a mianowicie osobowość Kościoła i wspólnota zostały spłaszczone.

Marek Marczewski - Lublin

\section{Ks. Leszek MISIARCZYK, Osiem „logismoi” w pismach Ewagriusza z Pontu, Tyniec - Kraków 2007, Wydawnictwo Benedyktynów, ss. 424.}

Podczas ostatnich kilkudziesięciu lat, szczególnie dzięki ważnym naukowym książkom A. Guillaumonta (Le „Kephalaia gnostica” d'Évagre Pontique et l'histoire de l'Origenisme chez les Grecs et chez les Syriens, Paris 1962), G. Bunge (Ewagriusz $z$ Pontu - mistrz życia duchowego, thum. J. Bednarek - A. Jastrzębski - A. Ziernicki, ŹM 19, Tyniec-Kraków 1998), a w Polsce - L. Nieściora (Anachoreza w pismach Ewagriusza z Pontu, Tyniec - Kraków 1997), wzrosło ogromnie zainteresowanie myślą teologiczno-ascetyczną Ewagriusza z Pontu, chociaż nie osiągnęło ono jeszcze takiego poziomu jak podejmowane we wszystkich zakątkach świata (Japonia!) badania nad twórczością duchowego ojca myśli pontyjskiego mnicha - Orygenesa. Wciąż pozostaje do przebadania szereg szczegółowych zagadnień dotyczących ewagriańskiej koncepcji życia duchowego i jej genezy. Nowe studia poświęcone „ojcu chrześcijańskiej literatury duchowej" - jak nazwał Ewagriusza O. Chadwick (John Cassian, 